\title{
Prebiotic, Probiotic and Symbiotic as Alternative to Antibiotics on the Performance and Immune Response of Broiler Chickens
}

http://dx.doi.org/10.1590/1516-635x1603279-284

\section{-Author(s)}

Murarolli VDA

Burbarelli MFC"

Polycarpo GV"

Ribeiro PAPII

Moro MEG'II

Albuquerque $\mathrm{R}^{\mathrm{V}}$

Master in Animal Nutrition and Production - School of Veterinary and Animal Sciences, FMVZ - USP

" Graduate studentin Animal Nutrition and Production - School of Veterinary and Animal Sciences, FMVZ - USP

III Professor-School of Animal Sciences and Food Engineering, FZEA- USP

Iv Professor, Department of Animal Nutrition and Production - School of Veterinary and Animal Sciences, FMVZ - USP

\section{Mail Address}

Corresponding author e-mail address: Ricardo de Albuquerque

Faculdade de Medicina Veterinária e Zootecnia da USP - FMVZ VNP

Rua Duque de Caxias Norte, 225

13635-900 - Pirassununga - SP

E-mail: ricalbuq@usp.br

\section{nKeywords}

Alternative additives, performance enhancers, vaccine titerss.

\section{ABSTRACT}

This study aimed to evaluate diets supplemented with prebiotic, probiotic and symbiotic as an alternative to antibiotics on the performance and immune response against the virus of Newcastle disease in broiler chickens. 1,400 one-day old male Cobb 500 chicks were raised until 42 days old in a completely randomized design with $2 \times 2+1$ factorial scheme with seven replications. The treatments were: diet without supplementation (base diet - BD), BD + prebiotic, BD + probiotic, BD + symbiotic (prebiotic + probiotic), and BD + antibiotic. The parameters evaluated were performance and antibody serum titers against Newcastle disease. No antibiotic effect was observed on performance. The symbiotic provided better results for weight gain and feed:gain ratio until 21 days old than isolated additives. At 28 days old, the broilers fed diets with prebiotic presented better feed: gain ratio. In the same period ( $28 \mathrm{~d}$-old), there was an antibody production increase against the Newcastle disease virus in the group supplemented with prebiotic. It can be concluded that the utilization of symbiotic in broiler chickens' diets can substitute performance enhancing antibiotics. The inclusion of prebiotic in the diet improves feed: gain ratio at 1-28 days old. The chickens' immune response increases at 28 days against the Newcastle disease virus in the group supplemented with prebiotic.

\section{INTRODUCTION}

In poultry production, the main objective is to obtain high yield and quality of the final products. Therefore, antimicrobial additives, including antibiotics, have been used in poultry diet (Loddi et al., 2000). The main concern is that the continuous use of antibiotics may develop and disseminate resistant bacterial populations and that this resistance may be transferred to pathogenic microorganism, becoming a risk to human and animal health (Dawson \& Pirvulescu, 1999; Menten \& Loddi, 2003).

This has led researchers to develop alternatives that keep high yield without harming human and animal health. The utilization of prebiotics, probiotics and symbiotics (Furlan et al., 2004) are among these alternatives. Probiotics, live culture of beneficial microorganisms, have beneficial actions on the host through the competition for linking sites and nutrients, production of antibacterial substances, suppression of ammonia production, neutralization of enterotoxins, in addition tostimulating the immune system (Fuller, 1989; Jin et al., 1997; Andreatti Filho \& Sampaio, 2000; Silva, 2000; Andreatti Filho \& Silva, 2005).

Gibson \& Roberfroid (1995) defined prebiotics as the food ingredients that provide beneficial effect to the host by selectively stimulating the growth and/or metabolism of a limited group of bacteria in the intestinal tract, acting closely to probiotics because it 
would constitute the "food" of probiotic bacteria and also blocking adherence sites, immobilizing and reducing the fixation capacity of pathogenic bacteria in the intestinal mucous (Silva, 2000; Andreatti Filho \& Silva, 2005). This association favors the intestinal microbiota by the action of prebiotics that are able to link themselves to the fimbriae of pathogenic bacteria, conducting them along the fecal bolus, stimulating the growth and accelerating the metabolism of a limited number of non-pathogenic microorganisms. The action of probiotics is added to this mechanism, making easy the nutrition of cells (enterocytes) that recover the digestive tract and provide balance and intestinal health to birds (Gibson \& Roberfroid, 1995).

The objective of this study was to evaluate the influence of supplementation with prebiotic, probiotic and symbiotic as an alternative to antibiotics on the performance and immune response against the Newcastle disease virus in broiler chickens.

\section{MATERIAL AND METHODS}

In this study, 1,400 one-day-old, male Cobb 500 chicks were distributed in a completely randomized design in a $2 \times 2+1$ factorial arrangement with five treatments and seven replications with 40 birds per experimental unit.

The diets were provided ad libitum during all experiment period and formulated according to the recommendations of Rostagno et al. (2005) (Table 1). The treatments were: diet without supplementation (base diet-BD); BD + prebiotic, mannanoligosaccharide derived from the cell wall of Saccharomyces cerevisaeyeast at a dose of $2.000 \mathrm{ppm} ; \mathrm{BD}+$ probiotic, Enterococcus ssp. (106 UFC/g) and Lactobacillus acidophilus (107 UFC/g) added to the diet at a dose of 400 ppm; BD + symbiotic, added to the diet at a dose of 2.000 ppm; and BD + antibiotic, 10 ppm avilamycin at a dose of $100 \mathrm{ppm}$ of the product. All additives were utilized substituting the inert material (kaolin), adjusting the percentage composition of different experimental diets. The performance variables were qualified at 7,14, 21, 28, 35 and 42 days.

The chicks were vaccinated against Marek's disease in the hatchery and against coccidiosis through drinking water in the first week of life. At 14 days old, they were vaccinated against Newcastle's disease (LaSota strain) via conjunctiva using lyophilized vaccine with live and attenuated VG/GA strain. The utilized vaccine dose was recommended by the manufacturer $(0.03$ $\mathrm{ml}$ ) and their diluent was utilized at the proportion
Table 1 - Composition and Calculated Values of Experimental Diets.

\begin{tabular}{lccc}
\hline Ingredients, \% & \multicolumn{3}{c}{ Phases } \\
\cline { 2 - 4 } & $1-21 \mathrm{~d}$ & $22-35 \mathrm{~d}$ & $36-42 \mathrm{~d}$ \\
\hline Corn & 52.26 & 57.11 & 63.70 \\
\hline Soybean meal & 40.13 & 34.00 & 28.00 \\
\hline Soybean oil & 3.52 & 4.90 & 4.50 \\
\hline Salt & 0.35 & 0.35 & 0.35 \\
\hline Kaolin & 1.24 & 1.60 & 1.60 \\
\hline Dicalcium Phosphate & 1.60 & 1.14 & 0.95 \\
\hline Methionine & 0.24 & 0.21 & 0.18 \\
\hline Vit.-Min Supplement ${ }^{(1)}$ & 0.30 & 0.30 & 0.30 \\
\hline Additives & & \\
\hline Prebiotic & 0.20 & 0.20 \\
\hline Probiotic & 0.04 & 0.04 \\
\hline Symbiotic & 0.20 & 0.20 & 0.04 \\
\hline Antibiotic & 0.01 & 0.20 \\
\hline Inert & $0.16-0.36$ & $0.19-0.39$ & $0.22-0.42$ \\
\hline Total & 100 & 100 \\
\hline \multicolumn{3}{c}{ Calculated Analysis } \\
\hline Metabolizable energy (kcal/kg) & 2950 & 100 \\
\hline Protein (\%) & 22.5 & 3100 & 3150 \\
\hline Methionine (\%) & 0.35 & 20.0 \\
\hline Methionine + cistine (\%) & 0.71 & 0.32 \\
\hline Calcium (\%) & 0.95 & 0.30 \\
\hline Available Phosporus (\%) & 0.45 & 0.95 \\
\hline
\end{tabular}

(1) Vitamin and mineral supplement in the initial phase ( $\mathrm{kg}$ by product): $35250 \mathrm{UI}$ vit. A, 8513 UI vit. D3, $6.0 \mathrm{mg}$ vit. K, $49.57 \mathrm{mg}$ vit. E, $6.67 \mathrm{mg}$ vit. B1, $15 \mathrm{mg}$ vit. B2, $8.33 \mathrm{mg}$ vit. B6, $40 \mathrm{mcg}$ vit. B12, $100 \mathrm{mg}$ niacin, $2.5 \mathrm{mg}$ folic acid, $39.13 \mathrm{mg}$ calcium panthotenate, $0.033 \mathrm{mg}$ biotin, $144.80 \mathrm{mg}$ iron, $144.50 \mathrm{mg}$ zinc, $28.53 \mathrm{mg}$ copper, $186.67 \mathrm{mg}$ manganese, $1.87 \mathrm{mg}$ iodine, $1.13 \mathrm{mg}$ selenium, $14 \mathrm{mg}$ antioxidant.

Vitamin and mineral supplement in the growth phase (kg by product): $29351 \mathrm{UI}$ vit A, $7088 \mathrm{UI}$ vit D3, $5.0 \mathrm{mg}$ vit $K, 41.33 \mathrm{mg}$ vit. E, $5.77 \mathrm{mg}$ vit. B1, $12.50 \mathrm{mg}$ vit. B2, $6.90 \mathrm{mg}$ vit. B6, $33.33 \mathrm{mcg}$ vit. B12, $83.33 \mathrm{mg}$ niacin, $2.07 \mathrm{mg}$ folic acid, $33.33 \mathrm{mg}$ calcium panthotenate, $0.27 \mathrm{mg}$ biotin, $144.80 \mathrm{mg}$ iron, $144.50 \mathrm{mg}$ zinc; $28.80 \mathrm{mg}$ copper, $186.50 \mathrm{mg}$ manganese, $1.87 \mathrm{mg}$ iodine, $1.13 \mathrm{mg}$ selenium, $14 \mathrm{mg}$ antioxidant. Vitamin and mineral supplement in the finishing phase ( $\mathrm{kg}$ by product): $23500 \mathrm{UI}$ vit A, $5675 \mathrm{UI}$ vit $D 3,4.0 \mathrm{mg}$ vit $K, 28.00 \mathrm{mg}$ vit. E, $4.47 \mathrm{mg}$ vit. B1, $10.00 \mathrm{mg}$ vit. B2, $5.53 \mathrm{mg}$ vit. B6, $26.67 \mathrm{mcg}$ vit. B12, $66.67 \mathrm{mg}$ niacin, $1.13 \mathrm{mg}$ folic acid, $26.67 \mathrm{mg}$ calcium panthotenate, $0.15 \mathrm{mg}$ biotin, $144.80 \mathrm{mg}$ iron, $144.50 \mathrm{mg}$ zinc; $28.80 \mathrm{mg}$ copper, $186.50 \mathrm{mg}$ manganese, $1.87 \mathrm{mg}$ iodine, $1.13 \mathrm{mg}$ selenium, $14 \mathrm{mg}$ antioxidant.

of $30 \mathrm{ml} / 1000$ vaccine doses. To evaluate the serum titers of antibodies against Newcastle, samples were collected at 14 days (before the vaccination) of two chicks per experimental unit, totalizing 14 birds per treatment that were individually identified, allowing the subsequent collection at 28 and 35 days by puncturing the ulnar vein. The samples were placed in eppendorf tubes without anticoagulant and centrifuged to obtain serum that was later submitted to immune enzymatic assay with ELISA (Enzyme-Linked Immune sorbent Assay) kit (Purchase et al., 1989).

The results were analyzed through the Statistical Analysis System (SAS, 2001). The data were submitted to normality test by Shapiro-Wilk's testand to homogeneity of variances test by Hartley's test (Ott, 

Polycarpo GV, Ribeiro PAP, Moro MEG Albuquerque $\mathbf{R}$
Murarolli VDA, Burbarelli MFC,

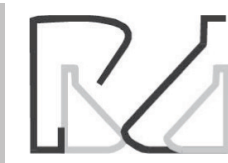

1983). The data that did not present normality distribution and/or homogeneity of variances were submitted to the logarithmic transformation to meet the statistical presuppositions. After the tests cited, the data were submitted to analysis of variance at $5 \%$ significance. The methodology of orthogonal contrasts was utilized to separate the effects of the treatments. The utilized contrasts were separated into effect of prebiotic, effect of probiotic, interaction (symbiotic effect), and antibiotic effect against the effect of treatments with alternative additives (prebiotic and/or probiotic)

\section{RESULTS AND DISCUSSION}

The averages of weight gain (WG), feed intake (FI) and feed:gain ratio (F:G) of broilers at 01-07, 01-14, 01-21, 01-28, 01-35 and 01-42 days old are shown in Table 2. For the intervals of 01-07, 01-14 and 01-21 days old, the significant effect of the additive interaction on WG and F:G was observed. The symbiotic treatment presented better results when compared to separately tested additives. In the interval of 1-28 days old, there

\section{Prebiotic, Probiotic and Symbiotic as Alternative to Antibiotics on the Performance and Immune Response of Broiler Chickens}

was improvement only in $\mathrm{F}: \mathrm{G}$, and an isolated effect of the prebiotic was observed.

Under the conditions of this experiment, it was not possible to verify significant differences on $\mathrm{Fl}$ of chickens or the effect of treatments for WG after 28 days of breeding. Chickens fed diets containing antibiotic presented similar performance to those that were fed diets containing alternative additives, showing that the utilization of symbiotic may represent a viable option to substitute antibiotics as performance enhancers.

On the other hand, Vargas Jr. et al. (2000), Maiorka et al. (2001) and Loddi (2003) did not observe a significant difference in the utilization of symbiotic in the diets when compared to other treatments in the 21-day-old period. Vargas Jr. attributes this result to the low sanitary conditions in which the experiment was carried out and that could be really crucial in such evaluations. However, Santin et al. (2001) observed that supplementation of $0.01 \%$ and $0.02 \%$ of the cell wall of $S$. cerevisiae as prebiotic provided higher values of $F: G$ when compared to the non-supplemented diet, in the periods of 21 and 42 days old.

Table 2 - Performance of broiler chickens in the intervals: 01-07; 01-14;01-21;01-28; 01-35 and 01-42 days old, under different treatments.

\begin{tabular}{|c|c|c|c|c|c|c|c|c|c|c|}
\hline \multicolumn{7}{|c|}{ Treatments $^{2}$} & \multicolumn{4}{|c|}{ Probability } \\
\hline \multirow[t]{2}{*}{ Variables $^{1}$} & \multicolumn{2}{|c|}{ Without Probiotics } & \multicolumn{2}{|c|}{ With Probiotics } & \multirow[b]{2}{*}{ Atb } & \multirow[b]{2}{*}{$C V(\%)$} & \multirow[b]{2}{*}{ Preb } & \multirow[b]{2}{*}{ Prob } & \multirow[b]{2}{*}{ Inter } & \multirow[b]{2}{*}{ Atb } \\
\hline & $\begin{array}{l}\text { Without } \\
\text { Preb }\end{array}$ & With Preb & $\begin{array}{l}\text { Without } \\
\text { Preb }\end{array}$ & With Preb & & & & & & \\
\hline \multicolumn{11}{|c|}{ 01-07 days } \\
\hline WG & 120.14 & 118.43 & 108.14 & 120.28 & 118.57 & 5.17 & 0.0025 & 0.0031 & 0.0001 & 0.1155 \\
\hline $\mathrm{FI}$ & 132.32 & 135.59 & 133.90 & 133.67 & 136.69 & 2.66 & 0.2497 & 0.8990 & 0.1889 & 0.1341 \\
\hline$F: G$ & 1.10 & 1.14 & 1.23 & 1.11 & 1.15 & 4.84 & 0.0007 & 0.0001 & 0.0001 & 0.3472 \\
\hline \multicolumn{11}{|c|}{ 01-14 days } \\
\hline WG & 421.71 & 413.28 & 394.00 & 422.10 & 417.14 & 3.61 & 0.0282 & 0.0352 & 0.0002 & 0.1478 \\
\hline $\mathrm{FI}$ & 525.07 & 530.72 & 540.15 & 526.18 & 537.01 & 2.83 & 0.4598 & 0.3505 & 0.0875 & 0.4727 \\
\hline$F: G$ & 1.24 & 1.28 & 1.37 & 1.24 & 1.28 & 4.03 & 0.0001 & 0.0001 & 0.0001 & 0.2363 \\
\hline \multicolumn{11}{|c|}{ 01-21 days } \\
\hline WG & 885.85 & 876.28 & 850.71 & 888.71 & 875.85 & 2.21 & 0.0162 & 0.0508 & 0.0002 & 0.5443 \\
\hline $\mathrm{FI}$ & 1193.97 & 1211.24 & 1211.13 & 1202.13 & 1204.77 & 2.55 & 0.7355 & 0.7420 & 0.2873 & 0.8101 \\
\hline$F: G$ & 1.35 & 1.38 & 1.42 & 1.35 & 1.37 & 2.81 & 0.1016 & 0.0424 & 0.0001 & 0.4078 \\
\hline \multicolumn{11}{|c|}{ 01-28 days } \\
\hline WG & 1504.00 & 1510.86 & 1479.57 & 1494.71 & 1507.29 & 2.15 & 0.3726 & 0.1054 & 0.7355 & 0.3900 \\
\hline $\mathrm{FI}$ & 2169.55 & 2162.33 & 2145.85 & 2149.40 & 2168.84 & 2.17 & 0.9214 & 0.3282 & 0.7719 & 0.4492 \\
\hline $\mathrm{F}: \mathrm{G}$ & 1.44 & 1.43 & 1.46 & 1.44 & 1.44 & 1.26 & 0.0158 & 0.0592 & 0.4022 & 0.5435 \\
\hline \multicolumn{11}{|c|}{ 01-35 days } \\
\hline WG & 2198.29 & 2184.43 & 2151.43 & 2180.86 & 2199.29 & 2.32 & 0.6870 & 0.1975 & 0.2665 & 0.2304 \\
\hline $\mathrm{FI}$ & 3365.28 & 3352.54 & 3314.48 & 3333.00 & 3357.71 & 2.28 & 0.9236 & 0.2482 & 0.6046 & 0.4852 \\
\hline $\mathrm{F}: \mathrm{G}$ & 1.53 & 1.53 & 1.54 & 1.53 & 1.53 & 1.25 & 0.6107 & 0.8502 & 0.2860 & 0.3742 \\
\hline \multicolumn{11}{|c|}{ 01-42 days } \\
\hline WG & 2829.14 & 2817.86 & 2794.71 & 2801.57 & 2842.00 & 2.16 & 0.9254 & 0.2880 & 0.7015 & 0.1785 \\
\hline $\mathrm{FI}$ & 4676.96 & 4687.67 & 4588.02 & 4646.41 & 4674.91 & 2.4 & 0.4233 & 0.1367 & 0.5796 & 0.4918 \\
\hline$F: G$ & 1.65 & 1.66 & 1.64 & 1.66 & 1.64 & 1.83 & 0.2618 & 0.5085 & 0.7908 & 0.4644 \\
\hline
\end{tabular}

'WG, weight gain (g); Fl, feed intake (g); F:G, feed:gain ratio (g/g). 2Preb, prebiotic; Prob, probiotic; Inter, interaction; Atb, antibiotic. 
The effects of additives on the average titers of vaccination antibodies against Newcastle disease, obtained by ELISA test, are presented in Table 3. At 14 days old, before the chickens' vaccination, the averages of analyzed antibody titers are considered passive antibodies (maternal origin). In this period, there was an effect of diets with antibiotic.

At 28 days, the chickens that were fed prebioticsupplemented diets presented better vaccine response. After the hatching, there is a gradual decline of the maternal antibody levels, and after 28 days old they are not observed anymore. Thus, the antibodies detected are originated from the acquired immune response. At 35 days old, no significant difference was observed in any of the tested contrasts.

Zulkifli et al. (2000), when evaluating antibody titers against Newcastle disease, observed the highest titers values in the treatment with probiotic compared to antibiotics; however, these results were only seen after a period of high temperature exposure, reinforcing the argument that the benefits of this additive are intensified in situations where there is some kind of challenge. Vesna et al. (2007) observed higher antibody titers against Newcastle disease in the treatment supplemented with MOS when compared to the control treatment.

Darpossolo et al. (2010) observed no differences in antibody titers against Newcastle disease in the treatment supplemented with $\beta$-Glucans, one of the compounds of Saccharomyces cerevisae yest wall, disagreeing with the present study. In addition, Nikpiran et al. (2013) studying effects of prebiotic and probiotic in immune response to the Newcastle disease observed that probiotic improved immune response to the vaccine in comparison to the prebiotic and control groups.

\section{CONCLUSION}

Under the experimental conditions, it was inferred that the use of symbiotic in the diets of broiler chickens can substitute performance enhancing antibiotics. The inclusion of prebiotic improves F:G until 28 days. There is an increase of the birds' immune response against Newcastle disease in the group supplemented with prebiotic at 28 days.

\section{REFERENCES}

Andreatti Filho RL, Sampaio HM. Probióticos e prebióticos: realidade na avicultura moderna. Avicultura Industrial 2000;1078:16-32.

Andreatti Filho RL, Silva EN. Probióticos e correlatos na produção avícola. In: Palermo Neto J, Spinosa HS, Górniak SL. Farmacologia aplicada à avicultura. São Paulo: Roca; 2005. Cap.15, p.225-248

Darpossolo FPB, Quintana LR, Magnani M, Oba A, Venâncio EV, CastroGoméz RJH. Avaliação do potencial imunoestimulante da Carboximetilglucana de Saccharomyces cerevisiae em frangos de corte (Gallus domesticus). Ciências Agrárias 2010;31(1):231-240.

Dawson KA, Pirvulescu M. Mananoligossacarídeos derivados de leveduras como moduladores da resposta imunológica e alternativas aos promotores de crescimento antimicrobianos. 9th Ronda Latino Americanada Alltech; 1999; Curitiba, Paraná. Brasil. p.33-41.

Fuller R. Probiotic in man and animals. Journal of Applied bacteriology 1989;66:365-378

Furlan RL, Macari M, Luquetti BC. Como avaliar os efeitos do uso de prebióticos, probióticos e flora de exclusão competitiva. Anais do 5 th Simpósio Técnico de Incubação, Matrizes de Corte e Nutrição; 2004 Balneário Camboriú, Santa Catarina. Brasil. p.6-28.

Gibson GR, Roberfroid MB. Dietary modulation of the human colonic microbiota: introducing the concept of prebiotics. Journal of Nutrition $1995 ; 125: 1401-1412$

Jin LZ, Ho YM, Abdullah N, Jalaludin S. Probiotic in poultry: modes of action. World's Poultry Science Journal 1997;53:351-368.

Loddi MM. Probióticos, prebióticos e acidificantes orgânicos em dietas para frangos de corte [tese]. Jaboticabal(SP): Universidade Estadual Paulista; 2003

Loddi MM, Gonzales E, Takita TS, Mendes AA, Roça RO. Uso de probiótico e antibiótico sobre o desempenho, o rendimento de carcaça e a qualidade da carcaça de frangos de corte. Revista Brasileira de Zootecnia 2000;29(4):1124-1131.

Maiorka A, Santin E, Sugeta SM, Almeida JG, Macari M. Utilização de prebióticos, probióticos e simbióticos em dietas para frangos. Revista Brasileira de Ciência Avícola 200;3(1):75-82.

Menten JFM, Loddi MM. Probióticos, prebióticos e aditivos fitogênicos na nutrição de aves. Simpósio de nutrição de aves e suínos; 2003; Campinas, São Paulo. Brasil. p.107-138.

Nikpiran H, Taghavi M, Khodadadi A, Athari SS. Influence of Probiotic and Prebiotic on broiler chickens performance and immune status. Journal of Novel Applied Sciences 2013;2(8):256-259.

Table 3 - Averages of antibody titers against the virus of Newcastle Disease in broiler chickens at 14, 28 and 35 days old (d).

\begin{tabular}{|c|c|c|c|c|c|c|c|c|c|c|}
\hline \multirow{3}{*}{ Periods } & \multicolumn{5}{|c|}{ Treatments } & \multirow[b]{3}{*}{ CV $(\%)$} & \multicolumn{4}{|c|}{ Probability } \\
\hline & \multicolumn{2}{|c|}{ Without Probiotics } & \multicolumn{2}{|c|}{ With Probiotics } & \multirow[b]{2}{*}{ Atb } & & \multirow[b]{2}{*}{ Preb $^{1}$} & \multirow[b]{2}{*}{ Prob } & \multirow[b]{2}{*}{ Inter } & \multirow[b]{2}{*}{ Atb } \\
\hline & Without Preb & With Preb & WithoutPreb & WithPreb & & & & & & \\
\hline $14 \mathrm{~d}$ & 2.17 & 2.36 & 2.48 & 2.30 & 1.95 & 18.79 & 0.9420 & 0.2377 & 0.0851 & 0.0008 \\
\hline $28 d$ & 2.44 & 2.69 & 2.37 & 2.76 & 2.69 & 18.78 & 0.0149 & 0.9854 & 0.6013 & 0.5691 \\
\hline $35 d$ & 2.62 & 2.75 & 2.99 & 2.75 & 2.80 & 15.78 & 0.6316 & 0.1246 & 0.1206 & 0.8233 \\
\hline
\end{tabular}

'Preb, prebiotic; Prob, probiotic; Inter, interaction; Atb, antibiotic. 
Ott RL. An introduction to statistical methods and data analysis. Wadsworth: 1983.

Purchase HG, Arp LH, Domermuth CH, Pearson JE. A Laboratory manual for isolation and identification of avian pathogens. 3rd ed. Duduque: Hunt Publishing Company; 1989. 227 p.

Ribeiro AML, Vogt LK, Canal CW, Cardoso MRI, Labres RV, Streck AF, Bessa MC. Effects of prebiotics and probiotcs on the colonization and immune response of broiler chickens challenged with salmonella enteritidis. Revista Brasileira de Ciência Avícola 2007;9(3):193-200.

Rostagno HS. Tabelas brasileiras para aves e suínos: composição de alimentos e exigências nutricionais. Viçosa, MG: Editora Universidade Federal de Viçosa; 2005. 141p.

Santin E, Maiorka A, Macari M, Grecco M, Sanchez JC, Okada TM, Myasaka AM. Performance and intestinal mucosa development of broiler chickens fed diets containing Saccharomyces cerevisae cell wall. Journal Applied Poultry Research 2001;10:236-244.
Silva EN. Probióticos e prebióticos na alimentação de aves. In: Conferência Apinco de ciência e tecnologia avícolas, 2000, Campinas, São Paulo. Brasil. v. 2, p. 241-251.

Statistical Analisys System- SAS. Institute Incorporation. SAS User's guide: statistics. 8th ed. 2001

Vargas Jr JG, Toledo RS, Albino LFT, Rostagno HS, Rocha DP. Uso de prebióticos em rações de frangos de corte. Revista Brasileira de Ciência Avícola 2000;2:31.

Vesna T, Lazarevic M, Sinovec Z, Tokic A. The influence of different feed aditives to performance and immune response in broiler chicken. Acta Veterinária 2007; 57(2/3):217-229.

Zulkifli I, Abdullah N, Azrin NM, Ho YW. Growth performance and immune response of two commercial broiler strains fed diets containing Lactobacillus cultures and oxutetracycline under heat stress conditions. British Poultry Science 2000;41:593-597. 
